\title{
Lupus miliaris disseminatus faciei: when a rare skin disease involves the eyelid
}

\section{Lupus miliaris disseminatus faciei: quando uma rara dermatose acomete a pálpebra}

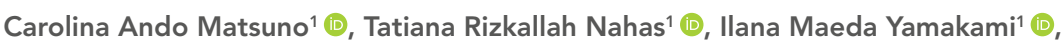
Nilceo S. Michalany² (1), Celia Simões Cardoso de Oliveira Sathler ${ }^{1}$ (i)

Keywords:

Lupus vulgaris; Skin diseases;

Eyelid; Granuloma; Scarring

Descritores:

Lúpus vulgar; Dermatopatias; Pálpebras; Granuloma; Cicatriz

Received on: 08/11/2020

Accepted on: Mar 31, 2021

Corresponding author: Carolina Ando Matsuno Avenida Jamaris, 543, Apto 171 - Planalto Paulista - Zip code: 04078-901. São Paulo,

$$
\text { SP, Brazil. }
$$

E-mail: camatsuno@gmail.com

Institution: rmandade da Santa Casa de Misericórdia de São Paulo, São Paulo, SP, Brazil.

Conflict of interest: no conflict of interest. Financial support:
the authors received no financial support for this work.

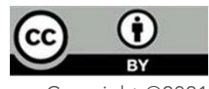

Copyright (C2021

\section{ABSTRACT}

The authors present a case of lupus miliaris disseminatus faciei, a rare skin disease of unknown etiology, which may cause unaesthetic scarring due to its difficult treatment. The histopathological examination of epithelioid granulomas with caseating necrosis, together with the clinical features, are important for diagnosis and early treatment with better results. Despite difficult and unsatisfactory treatment, there are ongoing studies on therapy to improve aesthetic and social impairment. This case report describes an initial misdiagnosis delaying appropriate treatment, and highlights the value of physical examination and clinical judgment for another pathological examination, whenever necessary, aiming at better treatment outcomes in daily practice.

\section{RESUMO}

Os autores apresentam um caso de lupus miliaris disseminatus faciei, uma dermatose rara, de etiologia desconhecida, que pode deixar cicatrizes não estéticas, pela dificuldade de tratamento. $\bigcirc$ exame histopatológico de granulomas compostos por células epitelioides, com necrose caseosa, e as características clínicas, são importantes para o diagnóstico e tratamento precoce, com melhores resultados. Apesar do tratamento difícil e insatisfatório, há estudos em andamento sobre terapias para melhorar o comprometimento estético e social. Este relato de caso descreve um diagnóstico inicial errôneo, que atrasou o tratamento adequado, e destaca o valor do exame físico e raciocínio clínico para solicitar outro exame anatomopatológico, quando necessário, de forma a obter melhores desfechos com o tratamento, na prática diária. 


\section{INTRODUCTION}

Lupus miliaris disseminatus faciei (LMDF) is a rare skin disease of inflammatory character and unknown etiology. It was described by Fox, in 1878, and predominantly affects young adults with brownish-erythematous papule pattern in the central region of the face, eyelids and periocular region, which can be accompanied by facial abnormalities. ${ }^{(1-3)}$ The histopathological findings of epithelioid granulomas with caseating necrosis and the clinical presentation are fundamental to make definitive diagnosis.(4) Differential diagnoses include acne, sarcoidosis, facial Afro-Caribbean childhood eruption (FACE), and bacterial and fungal infections. ${ }^{(1-3)}$ The difficult and unsatisfactory treatment has been currently studied, aiming to improve aesthetic and social impairment.

The study complies with the principles of Declaration of Helsinki. Written informed consent was obtained from the patient for publication of this case report and the accompanying images (Ethics Committee: CAAE 37558720.1.0000.5479).

\section{CASE REPORT}

A 29-year-old white, office assistant female, from São Paulo (SP), sought oculoplastic consultation, with complaints of "acne" lesions all over her face, including the lower eyelids with itchy, painful symptoms that started about 5 months before. She had started on oral treatment in another service with $300 \mathrm{mg}$ of Tetralysal ${ }^{\circ}$ (tetracycline) daily, for 30 days, with no improvement and $1 \mathrm{~g}$ tetracycline daily. Pathological study revealed possible rosacea. She denied prior lesions or similar cases in the family. Upon external examination, erythematous papules with a yellowish center, ranging from $2 \mathrm{~mm}$ to $4 \mathrm{~mm}$ in diameter, across the face and some arranged in a circle (Figure 1) in forehead and eyelid. Despite external eyelid involvement, tarsal conjunctiva and eyeball examination were normal.

Given no improvement with the medications used and considering the result of the previous histopathological examination, the medications were discontinued. She was initiated on oral isotretinoin $40 \mathrm{mg}$ per day, with control of coagulation factors, liver enzymes and lipid profile. After 2 months of isotretinoin, no improvement was observed and new lesions appeared; another biopsy was ordered to confirm or rule out the previous diagnosis, and guide appropriate treatment. Histopathologic examination showed granulomas consisting of epithelioid histiocytes, giant cells, lymphocytes and central necrosis in the dermis. It also presented perivascular and periadnexal mononuclear infiltrate (Figure 1C), compatible with diagnosis of lupus miliaris disseminatus faciei. Other laboratory tests included antinuclear (ANA), anti-Ro and anti-La antibodies, glucose-6-phosphate

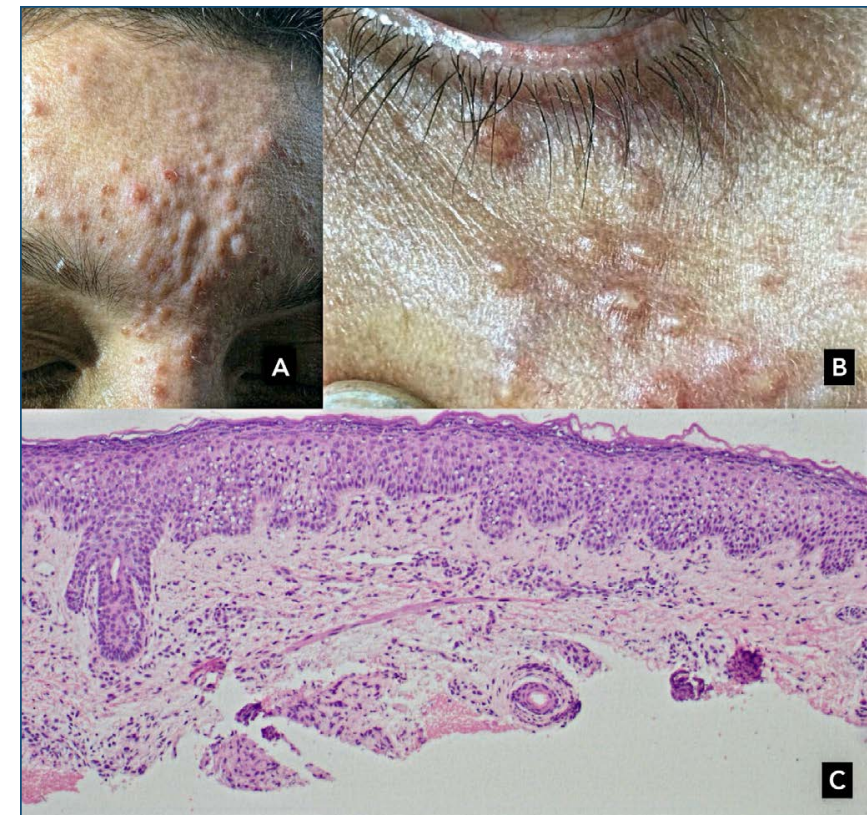

Figure 1. Brownish papular erythematous lesions. (A) On the forehead, (B) lower eyelid. (C) Histopathological examination shows granulomas consisting of epithelioid histiocytes, giant cells, lymphocytes and central necrosis.

dehydrogenase, VDRL, fluorescent treponemal antibody absorption (FTA-ABS). Since all tests results were normal, a new treatment was prescribed with oral dapsone $100 \mathrm{mg}$ per day, and $0.1 \%$ tacrolimus topical ointment twice a day.

Patient showed improvement after 3 months of treatment (Figure 2), but had to discontinue medication due to gastrointestinal symptoms. Oral prednisone $5 \mathrm{mg}$ and minocycline $100 \mathrm{mg}$ were prescribed as maintenance

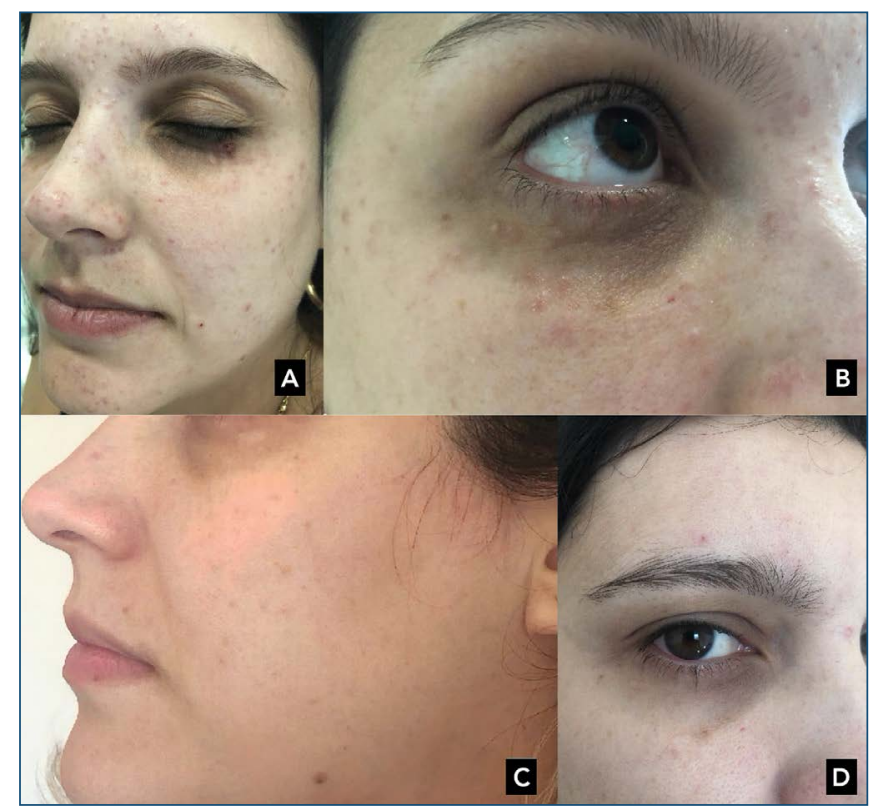

Figure 2. Improved aspect of the lesions. (A-B) After 3-month treatment. (C-D) Patient on no medications for over the year and no recurrence. 
treatment for 2 months, with significant resolution of lesions and further onset. The patient has remained with no symptoms and no medication for over one year.

\section{DISCUSSION}

Lupus miliaris disseminatus faciei is a rare skin condition that affects patients aged 20 to 40 years, with small, occasionally pustular, multiple brownish erythematous eruptions in the central region of the face, and typically in the lower eyelid. Extrafacial involvement has been occasionally reported. The eruption develops rapidly and remains in chronic course for 12 to 24 months, with spontaneous involution that can cause disfiguring scars. However, in several reports, it was possible to observe improvement and minimal scars associated with early treatment. . $^{(1-5)}$

Approximately 200 cases have been described in the literature, ${ }^{(1)}$ and their etiopathogenesis remains unknown. The association with Mycobacterium tuberculosis was suggested and ruled out due to absence of bacilli in the lesion, response to variable skin hypersensitivity tests, and failure of antituberculosis therapy. ${ }^{(5)}$ Some authors consider LMDF to be a variant of granulomatous rosacea, but disparate characteristics, such as self-limiting healing course, equal distribution between genders, presence of caseating necrosis, and absence of teleangiectasia hinder accepting this theory. An association with Demodex folliculorum has also been proposed due to involvement of the follicular wall. ${ }^{(1,6)}$

Histopathology presents dermal epithelioid granulomas with caseating necrosis, and with perivascular and lymphohistiocytic infiltrate. In more advanced stages, they may include perifollicular fibrosis. . $^{(1-5)}$

Due to its unknown etiology, treatment is difficult and there are few controlled studies in the literature. Oral tetracyclines (minocycline and doxycycline) have been relatively successful and are currently the treatment of choice.The therapeutic response usually starts after 3 to 6 months and a long maintenance period is required. ${ }^{(5)}$

Dapsone is an available, safe, affordable, and effective option. ${ }^{(1,7)}$ The mechanism of action in LMDF can be explained by its anti-inflammatory properties and decreased neutrophil response. Other medications, such as oral corticosteroids, isotretinoin, tranilast, metronidazole and isoniazid have also been used to treat and prevent onset of new lesions. ${ }^{(1-5,8,9)}$ Combination with topical tacrolimus and oral dapsone has also been successfully described. ${ }^{(1)}$ Topical $0.1 \%$ tacrolimus is a well-responsive immunomodulator in diseases associated with activation of T-lymphocytes and macrophages; 1,450nm diode laser and 1,565nm non-ablative laser resurfacing therapy has also shown improvement of lesions. ${ }^{(10,11)}$ Low-dose corticosteroids are prescribed to prevent scars. The use of 100\% trichloroacetic acid and laser have been successfully reported for treating scars. ${ }^{(12)}$

In this case, a multidisciplinary brainstorm helped to make the correct diagnosis. Due to the lack of response to tetracycline, considering the initial diagnosis of rosacea by a dermatologist, a new biopsy and an experienced pathologist were decisive for the correct diagnosis and proper treatment, resulting in improved facial lesions, eyelid with no scarring, and preserved eye function.

LMDF is a rare skin disease that can affect the face and eyelid region. Early clinical diagnosis combined with pathological study and treatment can minimize scar formation, with no aesthetic, functional eyelid, and social impairment for the patient.

\section{AUTHOR CONTRIBUTIONS}

Study concept and design: Matsuno C. A. e Sathler C. S. C. O.; Acquisition, analysis or interpretation of data: Matsuno C. A., Nahas T. R., Yamakami I. M., Michalany N. S. e Sathler C. S. C. O.; Drafting the manuscript: Matsuno C. A. e Sathler C. S. C. O.; Final revision: Sathler C. S. C. O., Nahas T. R., Yamakami I. M. e Michalany N. S.; Submission: Matsuno C. A.; Final approval of the version to be published: Matsuno C. A., Nahas T. R., Yamakami I. M., Michalany N. S. e Sathler C. S. C. O.

\section{REFERENCES}

1. Toda-Brito H, Aranha JM, Tavares ES. Lupus miliar disseminado da face. An Bras Dermatol. 2017;92(6): 856-8.

2. Marks R. Acne agminata. In: Champion RH, Burton JL, Ebling FJ, eds. Textbook of dermatology. Oxford: Blackwell Scientific Publications; 1992. p. 1862-3.

3. el Darouti $\mathrm{M}$, Zaher $\mathrm{H}$. Lupus miliaris disseminatus faciei - pathologic study of early, fully developed, and late lesions. Int J Dermatol. 1993;32(7):508-11.

4. Al-Mutairi N. Nosology and therapeutic options for lupus miliaris disseminates faciei. J Dermatol. 2011;38(9):864-73.

5. Amîruddîn D, Mii S, Fujimura T, Katsuoka K. Clinical evaluation of 35 cases of lupus miliaris disseminatus faciei. J Dermatol. 2011;3(6):618-20.

6. Nishimoto J, Amano M, Setoyama M. The detection of Propionibacterium acnes signatures in granulomas of lupus miliaris disseminatus faciei. J Dermatol. 2015;42(4):418-21.

7. Zhu YI, Stiller MJ. Dapsone and sulfones in dermatology: overview and update. J Am Acad Dermatol. 2001;45(3):420-34.

8. Uesugi Y, Aiba S, Usubua M, Tagami H. Oral prednisolone in the treatment of acne agminata. Br J Dermatol. 1996;134(6):1098-100.

9. Nomura H, Egami S, Kasai H, Yokoyama T, Fujimoto A, Sugiura M. A patient with lupus miliaris disseminatus faciei treated successfully with a combination of oral metronidazole and topical tacrolimus. J Dermatol. 2014;41(7):645-6.

10. Jih MH, Friedman PM, Kimyai-Asadi A, Friedman ES, Hymes SR, Goldberg LH. Lupus miliaris disseminatus faciei. Treatment with the 1450-nm diode laser. Arch Dermatol. 2005;141(2):143-5.

11. Beleznay K, Friedmann DP, Liolios AM, Perry A, Goldman MP. Lupus miliaris disseminatus faciei treated with $1,565 \mathrm{~nm}$ nonablative fractionated laser resurfacing: A case report. Lasers Surg Med. 2014;46(9):663-5.

12. Kang BK, Shin MK. Scarring of lupus miliaris disseminatus faciei: treatment with a combination of trichloroacetic acid. Dermatol Ther. 2014;27(3):168-70. 